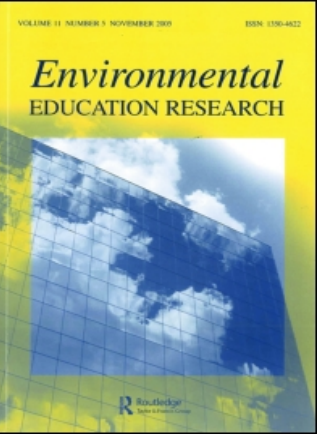

Environmental Education Research

\title{
Facilitating place-based environmental education through bird studies: an action research investigation
}

\author{
Özge Keşapli Can, Jennie F. Lane \& Armağan Ateşkan
}

To cite this article: Özge Keșapli Can, Jennie F. Lane \& Armağan Ateșkan (2017) Facilitating place-based environmental education through bird studies: an action research investigation, Environmental Education Research, 23:5, 733-747, DOI: 10.1080/13504622.2016.1233389

To link to this article: https://doi.org/10.1080/13504622.2016.1233389

Published online: 19 Sep 2016.

Submit your article to this journal $\sqsubset$

Џلll Article views: 336

Q View related articles $\sqsubset$

View Crossmark data $\longleftarrow$ 


\title{
Facilitating place-based environmental education through bird studies: an action research investigation
}

\author{
Özge Keşapli Can ${ }^{a}$, Jennie F. Lane ${ }^{b}$ and Armağan Ateşkan ${ }^{b}$ \\ aBilkent Erzurum Laboratory School, Biology Department, Bilkent University, Erzurum, Turkey; ${ }^{\text {b} G r a d u a t e ~ S c h o o l ~ o f ~}$ \\ Education, Bilkent University, Ankara, Turkey
}

\begin{abstract}
This study involved a workshop designed to support biology teachers in conducting birdwatching activities with their students and to promote place-based environmental education in Turkey. The instruments for collecting data were a workshop questionnaire and interviews. The findings revealed that initial response to the workshop was positive; participating teachers reported that the resources and strategies motivated them to conduct bird studies with students. They identified barriers and noted that the place-based education approach might help overcome many of these barriers. After the workshop, it became clear that participants' initial intentions to integrate birdwatching into their lessons were challenged by lack of confidence and time. To gain deeper insights into the outcomes of the project, the project coordinator used action research strategies to reflect on her practice and reveal implications for her continued efforts to promote bird and environmental education. She kept a journal, used reiterative reflection, and content analysis to analyse workshop evaluations and interviews. The coordinator recognized potentials and challenges for facilitating birdwatching and environmental education as part of her teaching career. This study shares some of her efforts to provide ongoing support and emphasizes that facilitation of environmental education needs time, commitment, and passion.
\end{abstract}

\section{ARTICLE HISTORY}

Received 25 April 2016

Accepted 15 August 2016

\section{KEYWORDS}

Action research; birdwatching; challenges to facilitation; teacher professional development; place-based education

\section{Introduction}

In today's world people have been losing contact with nature (Larson, Green, and Cordell 2011). More and more, people stay indoors and when they go outside, they are looking down at their mobile devices. To regain our connections with nature, we need to go outside, breathe the air, and look up. When we look up, we may see birds, even in the city. Upon seeing the birds, we can take time to observe them; their plumage, their behaviour, and their songs. Over time, their natural cycles can be studied: Do they stay year-round or are they just passing through? When they leave, where do they go and when will they come back? Watching birds and appreciating their habits and migrations provide great opportunities to reconnect with nature, to investigate the community, and learn about global connections.

This is a report of a research study conducted to promote the integration of birdwatching into biology classes in Turkey. Another objective was for the lead researcher to investigate her teaching practice, as well as the effectiveness of the project, through action research. Action research is a cyclic, iterative process where the focus of the research is subject to ongoing review and reflection through the repetition of action, reflection, and decision cycles (McAteer 2013). Therefore, action research for this 
study had a dual role: to facilitate the examination of programme effectiveness while simultaneously helping the project coordinator reflect on the practice of her passion and prepare for changes in her professional career (to become a formal classroom teacher). In the words of the project coordinator:

I have been a birdwatcher for 20 years and birds have changed the way I see the world. They improved my observational skills through developing my visual and auditory senses. During all the educational activities that I organized or participated in, I witnessed the excitement, amazement and happiness of people of all ages when they observe birds through binoculars or learn interesting facts. Because of this, I always felt it was my responsibility to share my enthusiasm and knowledge about birds and nature with other people.

One outcome of this study is the researchers learned the importance of providing ongoing support for teacher professional development in environmental education. To provide this support, facilitators need passion, commitment, and time. This study shares how a project coordinator, who clearly had the first two qualities, used action research to analyse and recognize the limitations of the third quality in her practice. She used strategies such as social media to facilitate her ongoing efforts and hopes that as she becomes more experienced, she will be able to provide long-term consulting services to encourage other teachers to integrate birdwatching into their practice.

\section{Birding education as a tool for place-based education}

An advantage to birdwatching is that the activity can take place by simply stepping outside to the school grounds or local community. This strategy of using local environments has been called place-based education (PBE). Sobel (2004) defines PBE as 'the process of using the local community and environment as a starting point to teach concepts in language arts, mathematics, social studies, science and other subjects across the curriculum' (7). Other educators and researchers have provided guidance for and discussed the merits of PBE (Gruenewald and Smith 2014; Knapp 2005; Krasny and Tidball 2009; Woodhouse and Knapp 2000). Learning about and within the natural world involves observing living and non-living aspects of an ecosystem. With PBE, the ecosystem consists of the school grounds and the local community. Non-living aspects of an ecosystem include soil, water, and weather while living aspects include wild species of plants and animals. Through PBE, children learn that they do not need to travel far to observe wildlife (Smith 2007). According to Broda (2007), schoolyard-enhanced learning is considered a subset of PBE. Schoolyards yield opportunities for all subject areas by providing real examples for the topics covered in the lessons, or simply by fostering motivation through changing the pace and place of lessons.

Since birds live nearly everywhere, they provide an ideal opportunity for becoming involved in the environment of the local community (Glowinski and Moore 2014; Louv 2005; Spartz and Shaw 2011). Even in a city park or school garden it is possible to observe seasonal differences in bird populations and behaviours. Birds are more easily seen than many other animals because of their attractive plumage and notable songs. They are very good indicators of the quality of their environment, so that many are considered flagship species for conservation studies (CEE 2004; Gregory et al. 2003). Greenwood (2007) explains that collaborative research among networks of amateurs has had a key role in ornithology and conservation science for many years.

Russo (2008) states that birds are constant reminders of nature; they offer great opportunities for PBE. It is practicable to observe seasonal differences in bird compositions and behaviours in a city park or school garden. Magpiong (2007) demonstrates that it is possible to integrate bird activities into language arts (symbolism and metaphors), social sciences (geography and bird migration), physics and mathematics (forces of flight), and arts (bird songs and colours of feathers).

Some birdwatching activities have been carried out by non-governmental organizations (NGO) in Turkey such as the East Mediterranean Bird Migration Education Project (executed by the researcher on behalf of Bird Research Society [KAD] in 1999), white stork education studies (KAD) and the Turkish section of the Spring Alive campaign (Nature Society). A biology teacher in one of the private schools in Istanbul founded a birdwatching club in the early 1990s that was active for about five years (K.A. Boyla, personal communication, 14 May 2015). More recently, a birdwatching club was founded in a 
high school in Istanbul in 2014 (H. Doğan, personal communication, 29 November 2014). Between 1995 and 2007, seven Bird Watching Schools were organized in Ankara and in Istanbul by NGO (KAD) in which mainly university students participated. Birdwatching clubs and NGOs organize activities that are open to the public on special days such as 'World Migratory Bird Day' in spring and 'World Bird Watching Day' in autumn. They also produce educational materials like leaflets and posters to raise public awareness and spark interest.

\section{Environmental education and PBE in Turkey}

According to Barnett (2009) PBE 'is an education philosophy rooted in environmental education and is also known as place-based learning, environment-based education and education for sustainability' (10). There have been a number of studies about environmental education in Turkey, including attitudes of students, pre-service teachers, and in-service teachers about environmental issues (Dinçer 2012; Erdogan, Marchinowski, and Ok 2009; Tuncer et al. 2005; YIlmaz and Andersen 2004). Other studies have investigated the resources and strategies used to increase environmental awareness and literacy (Erdoğan 2011; Erdogan, Uşak, and Bahar 2013; Güler 2009; Meydan, Bozyiğit, and Karakurt 2012). To date, there have been few investigations into PBE in Turkey (Köşker and Karabağ 2012; Ürey and Çepni 2014). Moreover, there have been no studies in Turkey that use birds as a resource to promote awareness of one's place.

\section{The problem and purpose}

Lying on a migratory route between Africa, Asia and Europe, Turkey accommodates numerous bird populations throughout the year. Ironically, birdwatching is a relatively new hobby in Turkey. Besides lack of awareness, the research team perceived that many Turkish educators felt they lacked the resources and time to conduct field trips to study birds. In Turkey, despite efforts to make learning more student-centred, biology education is still dominated by teachers lecturing about the content in textbooks. Most of the state schools do not have a laboratory and if they have, it is rarely used. According to the university entrance exam results, biology scores are lower than results for other subject areas (Telli et al. 2009).

Given the shortage of experiential learning in Turkish high school classes, our research team became interested in designing a project to help teachers become more aware of their 'place' as a resource for learning. In particular, we wanted to explore strategies and resources to motivate and prepare teachers to teach biology concepts using birdwatching in local environments.

To gain insights into what sparks interest in birding, the team interviewed experts and learned about birdwatching programs used by teachers around the world. Especially in the USA and UK, there are comprehensive nature education studies focusing on birds. These include the National Audubon Society (www.audubon.org), the Bird Education Network (BEN; www.birdeducation.org), Flying WILD (http://www.flyingwild.org/), the Cornell Lab of Ornithology (CLO; www.birds.cornell.edu), the Wisconsin Bird Conservation Initiative (www.wisconsinbirds.org/Education), Spring Alive (www.springalive.net), the Fledging Birders Institute (FBl; www.fledgingbirders.org), and the Royal Society for the Protection of Birds (RSPB; www.rspb.org.uk/discoverandenjoynature/).

Based on our review, we decided to apply for a small grant to fund a supply of birdwatching resources. These materials could be stored in a trunk and lent to teachers to conduct birding activities with their students. Studies have found that educational trunks and workshops spark teacher interest in environmental education (Estes 2003; Gillchrist 2004). We were awarded the grant on 1 October 2014.

Our team works within the Graduate School of Education of a non-profit foundation university in Ankara, Turkey. Two of the team members are academic staff and, during the time of the project, the third was a graduate studying to earn her teaching certificate in secondary biology education. The student became the project coordinator, designing the programme, identifying the contents of the resource trunk, and facilitating the workshop. 
Table 1. Background of interviewed teachers.

\begin{tabular}{lcl}
\hline Teacher & Teaching experience & \multicolumn{1}{c}{ School profile } \\
\hline T1 & 5 years & A private high school in Erzurum \\
T2 & 1 year & A private high school in Ankara \\
T3 & 1 year & A private high school in Bursa \\
T4 & 5 years & A private high school in Ankara \\
T5 & 3 years & A private high school in Ankara \\
T6 & 25 years & A state high school in İstanbul \\
\hline
\end{tabular}

\section{Participants}

The participants in this study were teachers who attended a birding education workshop conducted on November 29-30, 2014. Prior to developing the workshop, the researchers secured permission to conduct research through the Turkish Ministry of Education. The workshop was announced through a Bilkent University Graduate School of Education alumni Facebook group, and any teacher who expressed interest in the workshop was accepted. In total, 19 participants attended the workshop, including: one middle school science teacher and ten high school biology teachers from nine different private schools in Ankara, Erzurum, Kocaeli, and İzmir; one biology teacher from a state school in İstanbul; and seven pre-service biology teachers from the Bilkent Graduate School of Education (GSE). All participants completed an informed consent form that explained data would be collected to evaluate the outcomes of the workshop.

Six of the in-service biology teachers who attended the workshop and showed some interest in birding were interviewed after the workshop. Background information about the interviewed teachers is presented in Table 1.

\section{Methodology}

The team sought to determine whether these strategies would motivate teachers to conduct birding activities with their students. With an extensive background and passion for birding, the project coordinator was also keen on finding a way to combine her birding hobby with her future professional path of classroom teaching. The overarching research question for the project coordinator was: How can I, as a bird educator, promote the motivation and preparation of biology teachers to conduct bird studies with their students? To examine the effectiveness of her facilitation efforts, the project coordinator used action research strategies to triangulate and reflect upon outcomes of the project, especially perceptions of the participants. She also considered the following research questions as part of her investigation:

(1) Which strategies and resources do biology teachers indicate motivate them for birding education?

(2) Which strategies and resources do biology teachers indicate prepare them for birding education?

(3) What barriers and challenges have biology teachers faced or perceive they may face when conducting birding education?

(4) Do biology teachers indicate that birding will involve students in PBE?

The project coordinator kept a reflective journal in which she noted her thoughts and impressions regarding the analysis. She continually thought about her own efforts to motivate teacher interest in birdwatching and considered strategies she might use to integrate bird studies into her teaching practice. Action research has been used by a variety of studies to help practioners examine their practice and to improve education programs (Cardiff 2012; Papadimitriou 1995; Petrova, Garcia, and Bouzarovski 2016; Ragland 2006). During the birding workshop, the project coordinator reflected on her practice and considered ways to further support teachers and to promote their interest, motivation, and preparation. Figure 1 presents the action research cycles of this study. Through this 'cycle of enquiry' 


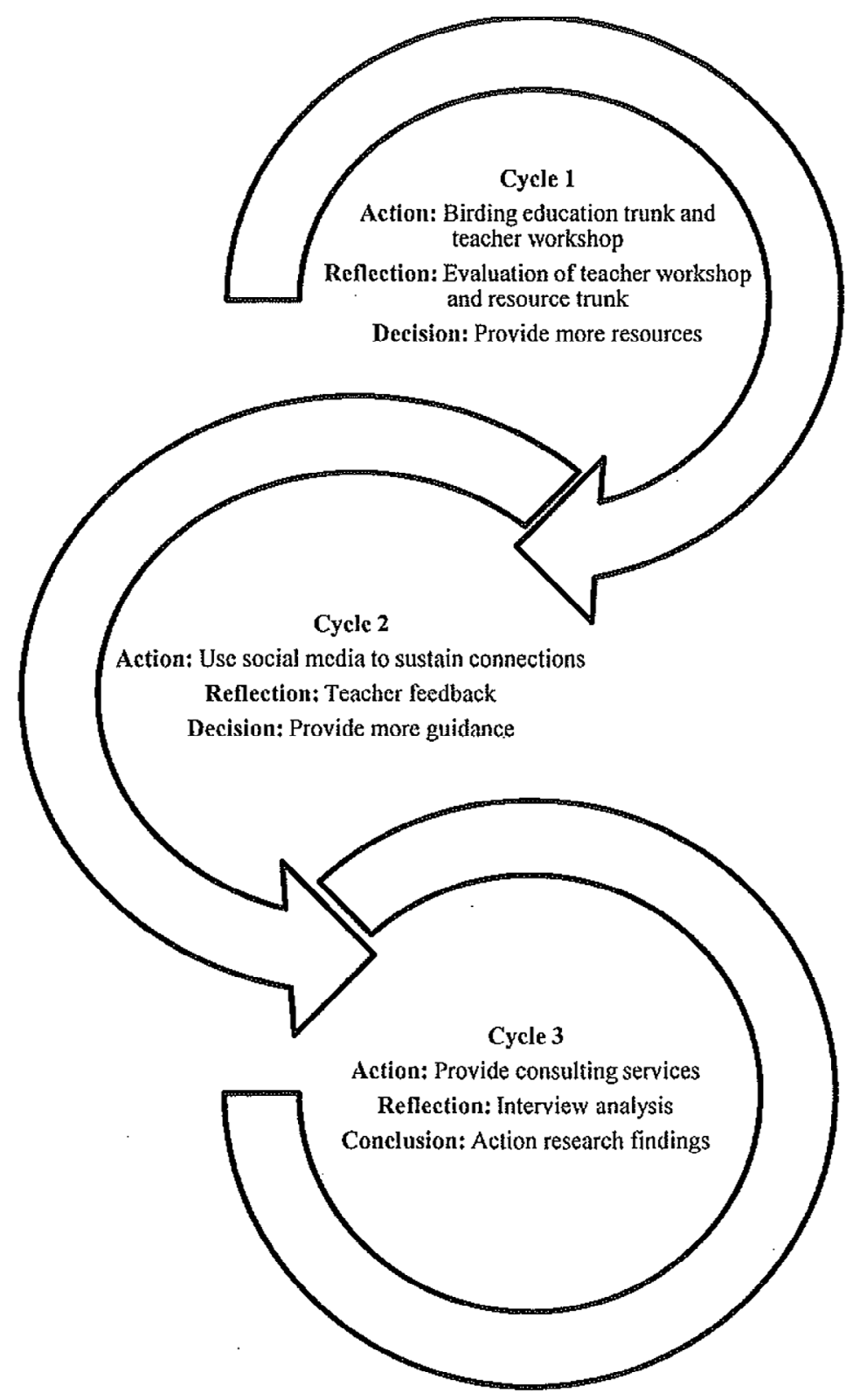

Figure 1. Action research cycles of the study.

the project coordinator in discussions with the research team was able to explore and analyse the dialectic relationship between theory, practice, research questions and personal experiences (Marshall and Rossman 1999).

\section{Instrumentation and data collection}

To provide the researchers with in-depth data and insights into the perceptions of the participants, this study developed tools to collect qualitative data. A questionnaire was designed to ascertain teachers' perceptions of how the workshop motivated and prepared them to do birdwatching programs with 
their students. The questionnaire included eight open-ended items related to expectations and opinions; it was patterned after workshop evaluations from other studies (mainly, CEE 2004) and adjusted to address the research questions (see Appendix 1). Through a workshop questionnaire, the insights of the 19 participating teachers were received immediately after the workshop.

The perceptions of six teachers were further assessed through interviews. The sessions took approximately half an hour (four were face-to-face; one was through Skype, and another by phone). The interviews addressed the research questions but remained semi-structured to allow teachers to openly express opinions and share insights (see Appendix 2).

\section{Data analysis}

Through a reiterative process, the data were reviewed and triangulated to gain insights to address the research questions. The data from the workshop questionnaires were translated from Turkish to English and compiled with their corresponding questions into a table. Using content analysis, the table was read several times to become familiar with the answers and to identify repeating themes and interesting points related to the research questions. Some recurring words were tabulated to determine frequencies.

The semi-structured interviews were recorded and listened to repeatedly. Key comments were transcribed, and translated from Turkish to English. Recurrent listening and transcribing key comments rather than the whole interview is a strategy to save time and energy of the researcher (Flick 2002; Strauss 1987). The key comments were read several times to become familiar with the data. Content analysis was used to identify repeating themes and other interesting points, and to comprehend the broader meaning of the interviews. Thus, the 'familiarization' approach was used in data analysis (Ritchie, Spencer, and O'Conner 2003, 221). Exemplary quotations were selected to highlight themes. Through these illustrative quotations, the researcher intended to use as many of the participants' own words as possible to present the clearest picture.

According to Patton (1999), in qualitative research, the credibility of the researchers has utmost importance because they are the primary instrument of data collection and analysis. The trustworthiness of this study was supported by the qualifications and expertise of the project coordinator along with her ongoing communications with other birding experts in Turkey. Action research strategies encouraged her to continually revisit the data and the outcomes of the project.

Shenton (2004) advocates that the use of triangulation is important for both the credibility and the confirmability of qualitative studies (in order to reduce the effect of investigator bias). According to Denzin (1978) and Patton (1999) there are four levels of triangulation. They are methods triangulation, triangulation of sources, analyst triangulation and theory/perspective triangulation.

Triangulation of sources was applied in this study. Through a questionnaire immediately after the workshop and through interviews with teachers who showed interest in birding, teachers' opinions were recorded at different points in time. Action research served as a conduit through which these sources of data were filtered and interpreted. Triangulation was also achieved because the workshop participants happened to have diverse backgrounds, with varying amounts of teaching experience, and worked in different settings (e.g. rural/urban and public/private schools). Two of the teachers had involved their students in birdwatching activities before this study.

One way triangulation was used in the study was to analyse teacher use of the resource materials. When questionnaire data was analysed, 17 of the participants indicated they planned to use the trunk; only two expressed reservations. In a different question, they were asked to share challenges to using the trunk and all participants shared concerns about maintenance and safety. When it became apparent that most of the teachers were not requesting the trunk, the project coordinator explored reasons during the interviews. Time was found as a recurrent theme mentioned by five of the six teachers. T2 stated,

Students may not want to give extra time for this activity. Especially for 11 th and 12 th graders, time is a big barrier because of the university entrance exam. Next year teachers' work load will increase at school more and this will cause time deficiency for extracurricular activities. 


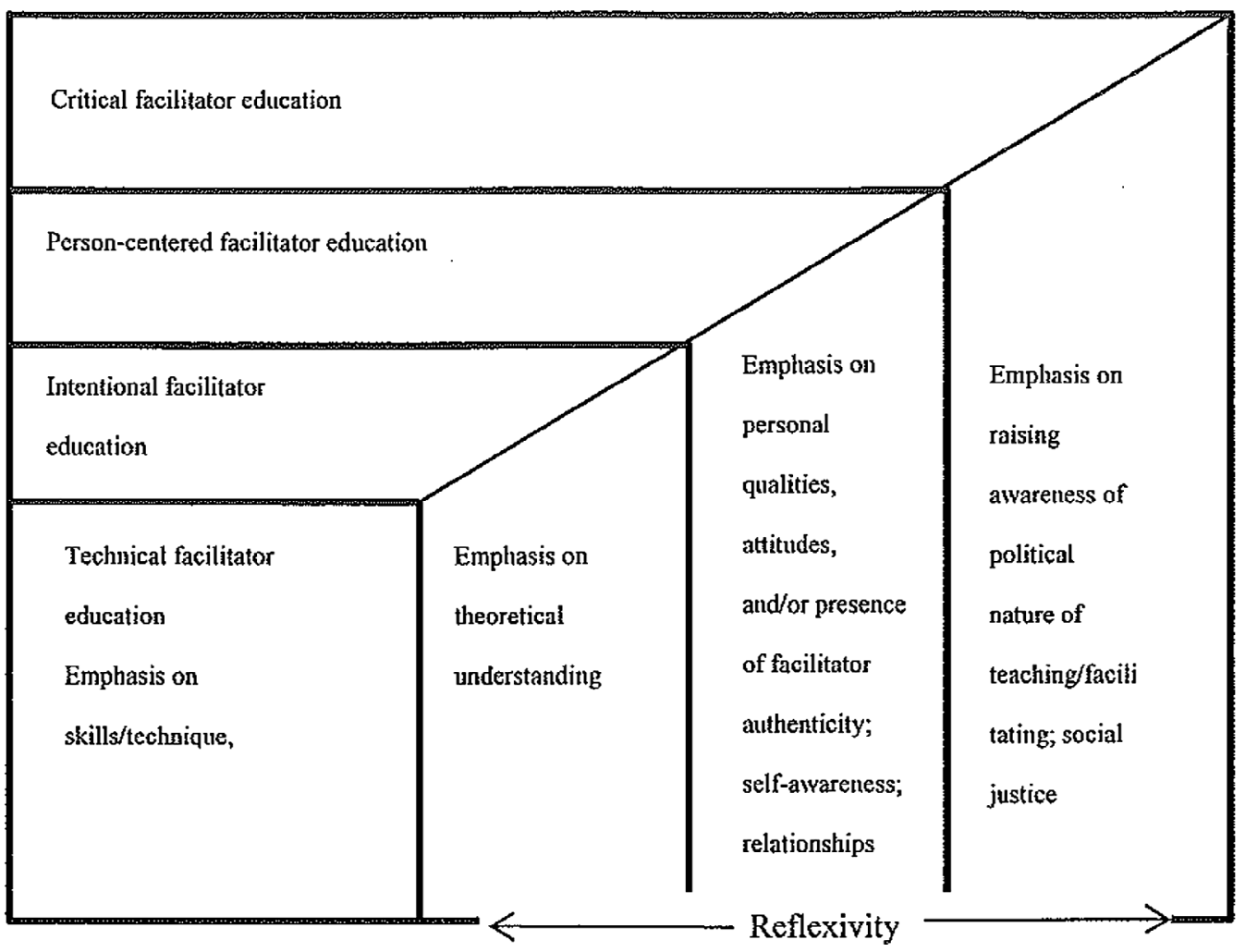

Figure 2. Thomas' dimensions of facilitator education (2005); adapted by Clayton, Smith, and Dyment (2014). Used with permission.

As part of the action research and data analysis, the research team referred an analytical framework (Figure 2) developed by Thomas $(2004,2005)$ and adapted by Clayton, Smith, and Dyment (2014). Through Thomas' typology, facilitator education advances from knowing what techniques to use, to understanding how the techniques apply theory to practice, to appreciating interactions among the facilitator and participants and outcomes, and finally recognizing the overarching goal of the education experience in transforming society. With each level, the facilitator becomes more conscious of their actions and decisions (Giddens 1984). This framework helped the project coordinator critique her practice and level of awareness. She consulted with the research team to share her reflections and decisions.

\section{Action research results: cycle 1}

\section{Action: birding education trunk and teacher workshop}

The birding education trunk was based on the Bird Monitoring Kit of the Wisconsin Bird Conservation Initiative and Wisconsin Society for Ornithology (http://wsobirds.org/learn-about-birds). The trunk included 14 binoculars, one telescope and tripod, and several bird identification guide books. The birding education trunk was lent to teachers who attended the workshop. A borrowing agreement and contents checklist were prepared for this purpose.

The birding education workshop was conducted in two parts on 29-30 November 2014. The first part provided teachers with theoretical background through sessions on nature education, $\mathrm{PBE}$, and birdwatching strategies. These were presentations provided by guest speakers along with some small group discussions and sharing. One of the guest speakers was a high school teacher that formed a birding club and another was an environmentalist who explained the ecological value of birds. The 
second part engaged teachers in practical training activities through a field trip to a local lake. Prior to the trip, the participants were introduced to the resource trunk and learned how to use the binoculars and guidebooks.

\section{Reflection: evaluation of teacher workshop and resource trunk}

There were 19 participants who completed the workshop evaluation questionnaire. The workshop questionnaires were examined to give insights into the research questions. Overall, participants evaluated the workshop positively; the majority indicated that the workshop exceeded (58\%) or fulfilled (26\%) their expectations. They described the experience using terms such as useful, successful, productive, and motivating. T1 stated that, 'The emphasis on the positive effects of bird studies on children and youth will be very helpful in convincing administrators to carry out these studies in our school.'T3 observed, 'I realized that my students are very far from nature and I should integrate nature into my lessons more.'

Respondents expressed that bringing together everything necessary for birdwatching in an educational trunk is a very good way to provide support and motivation for teachers. T4 noted that, 'Without all this equipment it is not possible to carry out bird studies. Teachers wouldn't even try to do this.'The group did report challenges and drawbacks to borrowing a trunk. The risk of damaging the equipment was stated as the main challenge by a majority of the participants $(n=15)$. They related concerns about needing an expert bird watcher to demonstrate how to use the equipment, discouraging student enthusiasm due to the need to share binoculars, obtaining permission to use the trunk, and taking time to teach every student how to use the binoculars.

\section{Decision: post-workshop communication needed}

Based on the workshop questionnaire and interviews, the workshop and the education trunk were effective strategies to promote teacher interest in conducting bird studies with their students. On the other hand, the teachers reported that the workshop was a very good start but it was not enough for them to feel totally prepared. They had concerns that students could ask unexpected questions related to bird identification, migration, feeding and behaviour, and they did not feel proficient in the subject. Upon review and reflection of the workshop evaluations, the project coordinator realized the importance of remaining connected to the participants to sustain their motivation. She decided to use social networking and launch a Facebook group.

\section{Action research results: cycle 2}

\section{Action: use social media to sustain connections}

The project coordinator launched the Facebook group, Kuşlarla Eğitim (Education with Birds), on December 2014 (www.facebook.com/groups/1566754193540781). The aim of this group was to motivate teachers to involve students in birding activities by informing them about resources and events related to birds and birding. The members were also reminded of the availability of the birdwatching trunk. All the teachers, pre-service teachers, and trainers who attended the workshop were made members of the group (except one who is not a Facebook user). Later other educators requested to join the group.

\section{Reflection: teacher posts on social media, phone calls, and email correspondence}

The project coordinator analysed the site in the summer of 2015. She learned that while most of the posts (58\%) were her own, 28 of the 32 members made several contributions and responses. During the follow-up interviews, one teacher noted, 'It is useful and logical to have such a Facebook group. Through reading the posts in the group I remember that I need to organize an activity. I mentioned some posts to my students.' 
The project coordinator also took phone calls from teachers and responded to emails. There was evidence that the participants had become more aware of birds in their local environments. They told her they were noticing sights and sounds they may not have attended to prior to the workshop. One of the pre-service teachers said that while he was running he noticed an unfamiliar bird. He said that, 'I was fully concentrated on running, but it took my attention. My perception has changed totally.' (Based on his description, the researcher identified the species as a starling.) Another teacher called the researcher in April when she heard an unknown birdsong. She asked the researcher to listen through the phone and the bird was identified as a blackbird. On the other hand, the team perceived a growing disinclination among the teachers to involve their students in birdwatching. Only six of the participants followed up with the project coordinator to borrow the trunk.

\section{Decision: provide more guidance}

The project coordinator decided to work with these six teachers extensively to provide guidance and support. She also interviewed them to gain greater insights into the benefits and challenges they faced when trying to integrate birding into their lessons.

\section{Action research results: cycle 3}

\section{Action: providing consulting services}

In the spring of 2015, the coordinator took on the role of birding consultant to the workshop participants who expressed interest in borrowing the trunk and conducting bird studies with their students. In some cases, she was a guest presenter in a class and led students on a field trip around their school grounds. Most of the time she used phone, email, and private Facebook messaging to provide teachers with advice and suggestions.

\section{Reflection: interview analysis}

The teachers responded positively to these efforts; they were motivated and encouraged by this support. In one of her personal reflections, the project coordinator stated,

It is clear to me that to feel totally prepared to conduct bird studies with their students, teachers need to gain more experience through the support of an expert. In addition to this, being aware of the presence of an expert willing to help them gives confidence and facilitates their endeavours.

Further reflections of the project coordinator are provided in Appendix 3.

From the interviews, the project coordinator learned that time was the main challenge to taking students on birding trips. Other concerns involved safety and student behaviour. The Turkish national curriculum is rigorous, and many schools concurrently implement an international course of study. For this reason, two teachers chose to create a club or an after school activity. The opinions and biases of colleagues and administrators proved to be an issue related to this effort. T5 stated, 'When I first mentioned my intention to found a birdwatching club in the meeting of the teachers committee, all the others laughed loudly. Later on some of them kept on making jokes about this.'Teachers also noted that getting permission for field trips is complicated by the need to secure approval from the school, department, and parents.

\section{Action research findings: workshop evaluations}

The project coordinator and research team found their results mirrored many other studies that involve teacher professional development through workshops. Immediately after the event, teachers are motivated and interested in applying what they learned. McCrea (2006) found this to be true when analysing the results of questionnaires from Flying WILD workshops offered through the Council for Environmental 
Education. According to the questionnaire data, workshop participants believed that they learned new information about birds (91\%) and bird related materials (94\%) at the workshops and were confident that they could use the Flying WILD materials (93\%). In a citizen science project conducted through the Cornell Laboratory of Ornithology, participants reported an increase interest in bird biology (Brossard, Lewenstein, and Bonney 2005). The researchers noted that improvements to the programme were needed to promote more long-term involvement in environmental issues.

Other studies have investigated barriers that prevent workshop participants from implementing environmental education. External barriers and logistic barriers, such as lack of time, funding and resources have been identified as significant factors (Ateşkan and Lane 2016; Dyment 2005; Ham and Sewing 1988; Ko and Lee 2003; Lane et al. 1994). Internal and personal barriers, such as programme content, and teachers' attitude and pedagogical knowledge are considered important as well (Jegede, Taplin, and Chan 2000; Rickinson et al. 2004; Shulman 1987; Simmons 1998).

Strategies to overcome these barriers were discussed with the interviewees. One of the most important findings of this study is that the PBE approach (e.g. using their school grounds to observe birds) may help overcome barriers inherent in obtaining permission for field trips and addressing safety. Teachers and pre-service teachers reported that because of the workshop they noticed birds more around their school, home, and community. T2 noted,

I used to think that all little birds were sparrows. My awareness increased significantly. Now, I always feel that there should be birds around. I started looking at details like their beak and feet shape. I used to think that birdwatching was a boring activity. Now I think differently.

T6 said that she noticed an unfamiliar crested bird in the school garden and realized that there actually were many of them (identified later by the researcher as a crested lark). She observed its behaviours and tried to take a photograph. She said her actions drew curious glances from other teachers and students. She said it was because they did not notice the birds, and they asked her what she was looking at. She confessed, 'I used to be like that, even though I studied biology.' Dyment (2005) also found that PBE at green school helps overcome many barriers to conducting field trips. An implication of this finding is that promoting PBE improves environmental education in schools (Barnett 2009; PEEC 2010).

Although local environments make birding more assessible, teachers expressed lack of confidence in identifying bird species with their students. Like the current study, Gilchrist (2004) learned that although teachers who participated in her workshops expressed their intention to conduct bird education studies with their students, they also reported that they need guidance with basic information for how to start. Interviewee T6 said that it is not enough to have extrinsic motivation sources such as training workshops, bird education trunks, Facebook groups, and support from consultant, and student interest. Intrinsic motivation for teachers is also crucial. She said that,

There are lots of barriers and challenges and it is in teacher's hands to keep on or give up. For me, the motivation occurred when one of my students came to me and asked why we are not doing any study about birds. His comment and my curiosity about birds resulted in a school birding club.

Supporting this idea, Dyment (2005) states that if internal values and perceptions of a teacher do not include outdoor learning, external training will have little effect.

It is clear, that participants feel they need to be more of a birding expert to lead students on birdwatching trips. However, Braus and Wood (1993) state that to conduct environmental education studies it is not necessary to be a scientist or a professional environmental educator. They explain that as an interdisciplinary field, environmental education requires many skills like communication skills, creativity and decision-making.

\section{Action research findings: providing long-term facilitative support for birding education}

Therefore, more than reiterating that the outcomes of workshops may be short-term in their effect, this study emphasizes that environmental education is a lifetime commitment. The role of the educator is to facilitate learning. As pointed out by researchers such as Clayton, Smith, and Dyment (2014) and 
Thomas (2008), it is important for the facilitator to be aware of their own practice. Referring to the analytical framework used to guide the action research in the current study, the project coordinator gained insights into multiple levels of her needs for facilitator education. She gained skills in conducting a workshop and explored how theories related to sense of place can be put into practice. Perhaps most important was coming to appreciate the ongoing role she will need to take if she wants to facilitate the integration of birding into biology classes throughout Turkey.

Following are two areas the research team identified that the project coordinator could continue to address. One area is to investigate further how to encourage teachers to take students on field trips and learn birding together, rather than feeling they need to be an expert first. She may relay what she learned from T6. This teacher, who was not a birding expert but was an experienced teacher, took her students on bird watching trips and learned with them. When they could not identify a bird together, they learned how to record details of the bird markings and sound to share with a local expert.

A second area is to explore how the Education with Birds Facebook group could continue to play a role in sustaining teacher interest. Research related to environmental education and social networks have begun to appear in the literature (Adams and Gynnild 2013; Robelia, Greenhow, and Burton 2011). The interviews revealed that although teachers do not actively use the site, it is an important platform in maintaining their interest on the topic, improving their knowledge, providing resources through archiving documents, and providing motivation to carry out studies with their students. The participants in this study think that teachers who carry out bird education activities with their students should share their experiences. In this way, they will be a model giving encouragement, and thereby increase the motivation of others. They reported that a Facebook group is an appropriate platform for this purpose.

Learning that these two areas may facilitate PBE through birding is one thing, actually addressing the areas is another. In her new career as a classroom teacher, the project coordinator has found that her classroom demands leave little time for providing consulting services to her friends and colleagues. As she becomes a more experienced teacher, she will be able to manage her time more effectively and revisit her birding passion. Through this research project, she has within her the knowledge of actions she can take to provide long-term birding support for PBE.

\section{Conclusion}

This project involved creating an educational birding resource trunk and preparing teachers, through a workshop, to borrow and use the trunk. The project coordinator, in an effort to sustain the teachers' motivation to use the trunk, created a Facebook page and provided consulting services. An underlying objective of this project was to use action research in a dual role: to facilitate the evaluation of project implementation and to aid the project coordinator in examining her teaching practice. Action research helped the coordinator determine strategies to keep teachers connected and motivated. Another purpose was to help teachers appreciate that with $\mathrm{PBE}$, the proximity of birds to the school grounds and community make the integration of birdwatching more feasible. This study, however, showed that even with availability of local resources, a single workshop is not enough to prepare and motivate teachers to conduct bird studies with their students. The same may be said of teacher preparation for other place-based activities on the school grounds, such as monitoring different wildlife species or gardening. Although the birding trunk has been borrowed seven times since the workshop, it is clear only a few of the teachers continue to express interest in the project. To sustain interest and build confidence, teachers could be provided with a series of workshops and consultants could be available to monitor their birdwatching activities and provide advice. Unfortunately, limitations of the project (funding and time) did not allow for these additional support services. The study was also limited by the small sample size and lack of resources to conduct longitudinal studies to further explore and overcome teachers' barriers. Nonetheless, this experience helped the project coordinator become more aware of what is involved in the facilitation of environmental education. She learned she will need to provide long-term consulting services if she wants other teachers to share her passion to bring more students outside; to look up and see the birds, and the world, around them. 


\section{Disclosure statement}

No potential conflict of interest was reported by the authors.

\section{Funding}

This work was supported by U.S. Department of State Federal Assistance Award [grant number S-TU-150-14-GR-145].

\section{Notes on contributors}

Özge Keşapli Can is a high school Biology and middle school Science teacher at Bilkent Erzurum Laboratory School. She has special interest in birds and involved in many national and international bird research, conservation and environmental education projects. She is interested in place-based environmental education.

Jennie F. Lane is an assistant professor at Bilkent University. She works with pre-service biology teacher. She works to integrate environmental and sustainability teaching competences into her teacher education programs.

Armağan Ateşkan is an assistant professor at Bilkent University Graduate School of Education. Her research interests are ICT in education, computational thinking, mLearning, education for sustainability, STEM education and outdoor education.

\section{References}

Adams, P., and A. Gynnild. 2013. "Environmental Messages in Online Media:The Role of Place." Environmental Communication 7 (1): 113-130. doi:10.1080/17524032.2012.754777.

Ateşkan, A., and J. Lane. 2016. "Promoting Field Trip Confidence: Teachers Providing Insights for Pre-service Education." European Journal of Teacher Education 39 (2): 190-201. doi:10.1080/02619768.2015.1113252.

Barnett, S. A. 2009. "Place-based Education and Teaching about Marin County Birds: Curriculum Development for Teachers." Unpublished master's thesis, Dominican University of California, San Rafael, CA. http://scholar.dominican.edu/cgi/ viewcontent.cgi?article=1149andcontext=masters-theses.

Braus, J. A., and D. Wood. 1993. Environmental Education in the Schools: Creating a Program That Works. Washington, DC: North American Association for Environmental Education Publications.

Broda, H. W. 2007. Schoolyard-enhanced Learning: Using the Outdoors as an Instructional Tool, K-8. Portland, ME: Stenhouse. http://www.stenhouse.com/html/schoolyard-enhanced-learning.htm.

Brossard, D., B. Lewenstein, and R. Bonney. 2005. "Scientific Knowledge and Attitude Change: The Impact of a Citizen Science Project." International Journal of Science Education 27 (9): 1099-1121. doi:10.1080/09500690500069483.

Cardiff, S. 2012. "Critical and Creative Reflective Inquiry: Surfacing Narratives to Enable Learning and Inform Action." Educational Action Research 20 (4): 605-622. doi:10.1080/09650792.2012.727653.

CEE (Council for Environmental Education) 2004. Project Wild: A Summary of Research Findings 1983-1995 and 19962003. Huston, TX: CEE. http://www.projectwild.org/documents/ProjectWILDSummaryofResearchFindings19831995and1996-2003_000.pdf.

Clayton, K., H. Smith, and J. Dyment. 2014. "Pedagogical Approaches to Exploring Theory-Practice Relationships in an Outdoor Education Teacher Education Programme." Asia-Pacific Journal of Teacher Education 42 (2): 167-185. doi:10.1 080/1359866X.2014.894494.

Denzin, N. K. 1978. Sociological Methods. New York: McGraw-Hill.

Dinçer, Z. 2012. "A Comparison of Selected Elementary Curricula in Regard to an Action Based Environmental Curriculum for Elementary Schools in Turkey." Unpublished master's thesis, Bilkent University, Ankara.

Dyment, J. E. 2005. "Green School Grounds as Sites for Outdoor Learning: Barriers and Opportunities." International Research in Geographical and Environmental Education 14 (1): 28-45.

Erdoğan, M. 2011. "The Effects of Ecology-Based Summer Nature Education Program on Primary School Students' Environmental Knowledge, Environmental Affect and Responsible Environmental Behavior." [Ekoloji temelli yaz doğa eğitimi programının ilköğretim öğrencilerinin çevreye yönelik bilgi, duyuşsal eğilimler ve sorumlu davranışlarına etkisi] Educational Sciences: Theory \& Practice 11(4): 2223-2237

Erdogan, M., T. Marchinowski, and A. Ok. 2009. “Content Analysis of Selected Features of K-8 Environmental Education Research Studies in Turkey." Environmental Education Research 15 (5): 525-548.

Erdogan, M., M. Uşak, and M. Bahar. 2013. "A Review of Research on Environmental Education in Non-traditional Settings in Turkey, 2000 and 2011." International Journal of Environmental and Science Education 8 (1): 37-57.

Estes, C. 2003. Developing, Evaluating, and Disseminating an Energy Education Resource Trunk. Unpublished master's thesis, University of Wisconsin, Wisconsin.

Flick, U. 2002. An Introduction to Qualitative Research. London: Sage.

Giddens, A. 1984. The Constitution of Society: Outline of the Theory of Structuration. Cambridge: Polity. 
Gillchrist, S. 2004. Getting Bird Conservation Education into Wisconsin Schools: A Summary of Telephone Interviews with Teachers. Bureau of Integrated Science Services, Wisconsin Department of Natural Resources, 52, Madison.

Glowinski, S., and F. Moore. 2014. "The Role of Recreational Motivation in the Birding Participation-Environmental Concern Relationship." Human Dimensions of Wildlife 19 (3): 219-233. doi:10.1080/10871209.2014.878966.

Greenwood, J. J. 2007. "Citizens, Science and Bird Conservation." Journal of Ornithology 148 (S1): 77-124.

Gregory, R. D., D. Noble, R. Field, J. Marchant, M. Raven, and D. W. Gibbons. 2003. "Using Birds as Indicators of Biodiversity." Ornis Hungarica 12 (13): 11-24.

Gruenewald, D. A., and G. A. Smith, eds. 2014. Place-based Education in the Global Age: Local Diversity. London, UK: Routledge.

Güler, T. 2009. "The Effects of an Ecology Based Environmental Education on Teachers' Opinions about Environmental Education." Education and Science 34 (151): 30-43.

Ham, S. H., and D. R. Sewing. 1988. "Barriers to Environmental Education." Journal of Environmental Education 19 (2): $17-24$.

Jegede, O., M. Taplin, and S. L. Chan. 2000. "Trainee Teachers' Perception of Their Knowledge about Expert Teaching." Educational Research 42 (3): 287-308.

Knapp, C. E. 2005. "The 'I-Thou' Relationship, Place-based Education, and Aldo Leopold." Journal of Experiential Education 27 (3): 277-285.

Ko, A. C., and J. C. Lee. 2003. "Teachers' Perceptions of Teaching Environmental Issues within the Science Curriculum: A Hong Kong Perspective." Journal of Science Education and Technology 12 (3): 187-204.

Köşker, N., and S. Karabağ. 2012. "Coğrafya eğitiminde yer temelli öğretim yaklaşımına ilişkin öğretmen görüşleri." [Teacher Opinions on Place-based Education Approach in Geography Education.] Türkiye Sosyal Araştırmalar Dergisi 16 (3): 123-137.

Krasny, M. E., and K. G. Tidball. 2009. "Community Gardens as Contexts for Science, Stewardship, and Civic Action Learning.” Cities and the Environment 2 (1): 1-18.

Lane, J., R. Wilke, R. Champeau, and D. Sivek. 1994. "Environmental Education in Wisconsin: A Teacher Survey." The Journal of Environmental Education 25 (4): 9-17.

Larson, L. R., G. T. Green, and H. K. Cordell. 2011. “Children's Time Outdoors: Results and Implications of the National Kids Survey." Journal of Park and Recreation Administration 29 (2): 1-20.

Louv, R. 2005. Last Child in the Woods: Saving Our Children from Nature-deficit Disorder. Chapel Hill, NC: Algonquin Press.

Magpiong, D. 2007. This Class is for the Birds. Fledging Birders Institute. http://www.fledgingbirders.org/teachers.html.

Marshall, C., and B. G. Rossman. 1999. Designing Qualitative Research. http://pages.cmns.sfu.ca/danielahadi/files/2013/01/ Marshall_Rossman.pdf.

McAteer, M. 2013. Action Research in Education. Thousand Oaks, CA: Sage.

McCrea, E. J. 2006. Flying Wild Program Evaluation Report. http://www.flyingwild.org/aboutus/documents/2006McCrea ProgramEvaluation.pdf.

MEB (Milli Eğitim Bakanlığı) 2009. The reasons of renewal of curriculum and the differences between behaviourist and conctructivist approach. [Öğretim programlarının yenilenme gerekçeleri ve davranışçı yaklaşım ile yapılandırmacı yaklaşım arasındaki farklar] Ankara: Ministry of National Education. Yazar.

Meydan, A., R. Bozyiğit, and M. Karakurt. 2012." The level of participants' expectations about the ecology based environment projects." [Ekoloji temelli doğa eğitimi projelerinin katılımcı beklentilerini karşılama düzeyleri] Marmara Geography Journal [Marmara Coğrafya Dergisi] 25: 238-255.

Papadimitriou, V. 1995. “Professional Development of In-service Primary Teachers in Environmental Education: An Action Research Approach." Environmental Education Research 1 (1): 85-97.

Patton, M. Q. 1999. "Enhancing the Quality and Credibility of Qualitative Analysis." HSR: Health Services Research 34 (5): 1189-1208.

PEEC (Place-based Education Evaluation Collaborative) 2010. The Benefits of Place-based Education: A Report from the Placebased Education Evaluation Collaborative. 2nd ed. http://tinyurl.com/PEECBrochure.

Petrova, S., M. Garcia, and S. Bouzarovski. 2016. "Using Action Research to Enhance Learning on End-use Energy Demand: Lessons from Reflective Practice." Environmental Education Research. doi:10.1080/13504622.2016.1144177.

Ragland, B. 2006. “Positioning the Practitioner Researcher: Five Ways of Looking at Practice." Action Research 4 (2): 165-182. doi: 10.1177/1476750306063990.

Rickinson, M., J. Dillon, K. Teamey, M. Morris, M. Y. Choi, D. Sanders, and P. Benefield. 2004. A Review of Research on Outdoor Learning. Shrewsbury: National Foundation for Educational Research and King's College London.

Ritchie, J., L. Spencer, and W. O'Conner. 2003. “Carrying out Qualitative Analysis." In Qualitative Research Practice: A Guide for Social Science Students and Researchers, edited by J. Ritchie and J. Lewis, 219-262. London: Sage.

Robelia, B. A., C. Greenhow, and L. Burton. 2011. "Environmental Learning in Online Social Networks: Adopting Environmentally Responsible Behaviors." Environmental Education Research 17 (4): 553-575.

Russo, M. 2008. "For the Birds! Seeing, Being, and Creating the Bird World." Young Children 63 (1): 26-30.

Shenton, A. K. 2004. "Strategies for Ensuring Trustworthiness in Qualitative Research Projects." Education for Information 22: 63-75.

Shulman, L. S. 1987. “Knowledge and Teaching: Foundations of the New Reform.” Harvard Educational Review 57 (1): 1-23. http://people.ucsc.edu/ ktellez/shulman.pdf. 
Simmons, D. 1998. "Using Natural Settings for Environmental Education: Perceived Benefits and Barriers." The Journal of Environmental Education 29 (3): 23-31.

Smith, G. A. 2007."Place-based Education: Breaking through the Constraining Regularities of Public School." Environmental Education Research 13 (2): 189-207.

Sobel, D. 2004. Place-based Education: Connecting Classrooms and Communities. Barrington, MA: The Orion Society.

Spartz, J. T., and B. R. Shaw. 2011. "Place meanings surrounding an urban natural area: A qualitative inquiry." Journal of environmental psychology 31 (4): 344-352.

Strauss, A. 1987. Qualitative Analysis for Social Scientists. Cambridge: Cambridge University Press.

Telli, S., P. Brok, C. Tekkaya, and J. Çakıroğlu. 2009. "Turkish Students' Perceptions of Their Biology Learning Environments: The Effects of Gender and Grade Level." Asian Journal of Educational Research and Synergy 1 (1): 110-124.

Thomas, G. 2004. "A Typology of Approaches to Facilitator Education." Journal of Experiential Education 27 (2): 123-140.

Thomas, G. J. 2005. “Dimensions of Facilitator Education.” In The IAF Handbook of Group Facilitation: Best Practices from the Leading Organisation in Facilitation, edited by S. Schuman, 525-541. San Francisco, CA: Jossey Bass.

Thomas, G. 2008. "Facilitate First Thyself: The Person-centered Dimension of Facilitator Education." Journal of Experiential Education 31 (2): 168-188.

Tuncer, G., H. Ertepinar, C. Tekkaya, and S. Sungur. 2005. “Environmental Attitudes of Young People in Turkey: Effects of School Type and Gender." Environmental Education Research 11 (2): 215-233.

Ürey, M., and S. Çepni. 2014. "The evaluation of the science based interdisciplinary school garden program's effect on students' attitudes towards science and technolgy lesson according to the different variables." [Fen temelli ve disiplinlerarasi okul bahçesi programinin öğrencilerin fen ve teknoloji dersine yönelik tutumlari üzerine etkisinin farkli değişkenler açisindan değerlendirilmesi] OMU Education Faculty Journal [OMÜ Eğitim Fakültesi Dergisi] 33 (2): $537-548$.

Woodhouse, J. L., and C. E. Knapp. 2000. "Place-based Curriculum and Instruction: Outdoor and Environmental Education Approaches." Thresholds in Education 27 (3/4): 31-35.

Yılmaz, O., and O. H. Andersen. 2004. "Views of Elementary and Middle School Turkish Students toward Environmental Issues." International Journal of Science Education 26 (12): 1527-1546.

\section{Appendix 1. Workshop questionnaire}

(1) To what extent were your expectations met during the workshop?

(2) Which part of the workshop did you like the most or did you find the most helpful for your teaching? Why?

(3) After this training do you feel more competent using bird education to help students understand their local environment?

(4) Will this workshop help you integrate bird education into your lessons/into the curriculum? How?

(5) Are you planning to use the bird education trunk with your students? When? How?

(6) What do you see as the potential benefits of using the bird education trunk?

(7) What do you see as the potential challenges of using the bird education trunk?

(8) Anything else you want to share? What else should be included in this training? Anything missing?

\section{Appendix 2. Interview questions}

(1) Did the workshop increase your motivation in conducting bird studies with your students? Did it make you feel more prepared to do bird studies with students?

(2) Will having a bird education trunk available motivate you to conduct bird studies with your students? What suggestions do you have to improve the availability and usability of the trunk?

(3) Did you do any bird education activities with your students after the workshop? If so, where did you take them?

(4) If so, did you do the activities during an extracurricular programme or as a part of a lesson during the school day?

(5) How many students joined the activity? Please provide observations about their interest and participation. What interested them the most, what would gain their interest better? What other effects did you notice the experience had on students?

(6) How did you (how would you) evaluate the benefits of bird education for your students depending on your experience?

(7) How has the Facebook group affected your practice? Do you find it useful/effective for motivating and providing information? Do you have any suggestions?

(8) How useful/helpful was it to have a bird expert (the researcher) as a consultant to help you plan and conduct bird studies? Would you be able to continue planning without a consultant in the future or would you need an expert to continue? If a birding expert was available to you in the future, what would you need from him or her? 
(9) What barriers or challenges have you faced (or do you think you'll face) trying to conduct bird studies with your students?

(a) Is finding time in the curriculum an issue? Will the conceptual framework, with connections to the national curriculum, assist you in relating bird studies to your teaching? What else would you need to help you make curricular connections?

(b) Is finding time and funding to take field trips an issue? Have you studied bird populations around the school grounds with your students? Would you consider doing this?

(10) Are you thinking to continue bird education studies with your students? What resources or any other kind of support do you think you would need?

(11) Do you find you notice birds more around your school, home and community? If so, can you share some examples?

\section{Appendix 3. Reflections of the project coordinator}

My aim for this project was to build teachers' capacity to conduct bird studies with their students. I sought to accomplish this by providing resources and strategies to motivate them and help them feel prepared. My research team and I decided to include an action research component to this study. During the project, I used reiterative reflection to evaluate our efforts.

Overall, I found evidence that the workshop interested all the teachers. However, this interest motivated only a small number of the teachers to actually implement activities with their students. Communications with these teachers revealed that they lacked confidence in many ways and needed guidance from me to help them feel prepared. Nonetheless, I was pleased when several teachers did follow up with me to seek advice on doing some activities with their students.

Bird watching is a passion of mine that will continue to play a significant role in my life. This study afforded me the opportunity to spread my passion to others through the formal education system. By educating teachers, I hoped to motivate and prepare them to, in turn, spread interest and knowledge about birds to their students. I learned, however, that long-term collaborations will be necessary to support teachers.

\section{Reflections, one year later}

A year after the workshop I conducted with my research team, I am still investigating how to relate my passion for birding to my teaching profession. I continue to provide some consultation services to other teachers, but I have to admit that being a first-year teacher has limited the amount of time available to maintain my networks and contacts.

In August of 2015, I became a high school biology and middle school science teacher at a private school in Eastern Turkey. I live on campus. Before the academic year started, I had a chance to watch birds in the field and begin a checklist of species. I witnessed the migration of hundreds of buzzards and bee-eaters. This motivated me to launch a birdwatching club in my first term.

I made a 5 min presentation to introduce a birdwatching club to students. Only four students registered for the club, but still it was a good start. We were lucky that there were binoculars at school, which took away one of the main challenges to starting a birdwatching club.

The club met for a few weeks; we walked around the campus and identified seven different bird species. Students learned how to use binoculars and a bird identification guide book. They prepared posters of the species that we observed on the campus, watched videos, played bird identification activities. The campus is newly established and there are very few trees, so there were limited observations, unfortunately. Toward the winter, when it became dark during the club hour, we still met and enjoyed our walks. We spotted one owl species, Little Owl, on the campus. It was an exciting discovery for students (made more so when the owl song became the signal used to announce the start and end of classes for a week). Eventually, it became too cold to go outside and student interest in just meeting and discussing birds waned. I considered changing the club to a nature club instead.

Besides the club, I also found opportunities to integrate bird concepts into my lesson plans. To create interest in biology and life in general, I used 5 min of one of my lessons to talk about owls and show the students an owl feather to explain how they can fly silently. In the middle school, while covering a friction topic I used birds as an example to discuss air and water resistance. I explained how cranes migrate in $\mathrm{V}$ formation and how gannets dive in an aerodynamic shape to catch fish. It attracted students' attention and increased their motivation for the lesson.

As I mentioned, I did make an effort to maintain the birding network started after the workshop. I posted 10 messages to the Facebook group Kuşlarla Eğitim, two of which related to my own experiences and the remainder bird related posts of others.

My first year of teaching has helped me appreciate comments the workshop teachers made about time being a challenge to taking students birding. In addition to time, I experienced other challenges related to student behaviours and weather conditions. Despite these pitfalls, I still believe in the benefits of using birds in my teaching both inside and outside the classroom. I'll keep on with my efforts. 